\title{
Policy and Practice of Work Ability: A Negotiation of Responsibility in Organizing Return to Work
}

Ida Seing, Christian Ståhl, Lennart Nordenfelt, Pia Bülow and Kerstin Ekberg

\section{Linköping University Post Print}

N.B.: When citing this work, cite the original article.

The original publication is available at www.springerlink.com:

Ida Seing, Christian Ståhl, Lennart Nordenfelt, Pia Bülow and Kerstin Ekberg, Policy and Practice of Work Ability: A Negotiation of Responsibility in Organizing Return to Work, 2012, Journal of occupational rehabilitation, (22), 4, 553-564.

http://dx.doi.org/10.1007/s10926-012-9371-3

Copyright: Springer Verlag (Germany) http://www.springerlink.com/?MUD=MP

Postprint available at: Linköping University Electronic Press http://urn.kb.se/resolve?urn=urn:nbn:se:liu:diva-73888 


\section{Authors of the article:}

Ida Seing, Christian Ståhl, Lennart Nordenfelt, Pia Bülow, Kerstin Ekberg

\section{Title of the article:}

Policy and Practice of Work Ability: A Negotiation of Responsibility in Organizing Return to Work

\section{Affiliations and addresses of the authors:}

Ida Seing (Corresponding author)

National Centre for Work and Rehabilitation, Department of Medical and Health Sciences, Linköping University, 58183 Linköping, Sweden

E-mail: ida.seing@liu.se

Telephone: +46(0)10-1034963

Fax: +46 (0)10-103 5100

\section{Christian Ståhl}

National Centre for Work and Rehabilitation, Department of Medical and Health Sciences, Linköping University, 58183 Linköping, Sweden

HELIX VINN Exellence Centre, Linköping University, Linköping, Sweden

\section{Lennart Nordenfelt}

Division of Health and Society, Department of Medical and Health Sciences, Linköping University, 58183 Linköping, Sweden

\section{Pia Bülow}

Department of Behavioral Science and Social Work, School of Health Sciences, Jönköping University, Box 1026, 55111 Jönköping

\section{Kerstin Ekberg}

National Centre for Work and Rehabilitation, Department of Medical and Health Sciences, Linköping University, 58183 Linköping, Sweden

HELIX VINN Exellence Centre, Linköping University, Linköping, Sweden 


\begin{abstract}
Purpose

In welfare policy and practical work it is unclear what the concept of work ability involves and assessments may be different among involved actors, partly due to a lack of theoretical research in relation to regulations and practice. Based on theoretical and legal aspects of work ability the aim of the study is to analyze stakeholders' perspectives on work ability in local practice by studying multi-stakeholder meetings.
\end{abstract}

\title{
Methods
}

The material comprises nine digitally recorded multi-stakeholder meetings. Apart from the sick-listed individual, representatives from the public Social Insurance Agency, health care, employers, public employment service and the union participated in the meeting. The material was analyzed using qualitative content analysis.

\section{Results}

Three perspectives on work ability were identified: a medical perspective, a workplace perspective and a regulatory perspective. The meetings developed into negotiations of responsibility concerning workplace adjustments, rehabilitation efforts and financial support. Medical assessments served as objective expert statements to legitimize stakeholders' perspectives on work ability and return to work.

\section{Conclusions}

Although the formal goal of the status meeting was to facilitate stakeholder collaboration, the results demonstrates an unequal distribution of power among cooperating actors where the employers had the "trump card" due to their possibilities to offer workplace adjustments. The employer perspective often determined whether or not persons could return to work and if they had work ability.

Key words: work ability, return to work, employers, multi-stakeholder meeting, cooperation 


\section{Introduction}

In several western countries, work ability is a central concept in legislation regulating social insurance. A focus on individuals' abilities rather than impairments has also come to shape disability management services in order to counter social exclusion from the labour market [12]. However, in welfare policy and practical work it is unclear what the concept of work ability involves and definitions and assessments can be different among involved organizations and professionals [3].

As research on work ability is conducted within several disciplines and with different theoretical approaches the concept may be understood and used differently. There is no established common method for measuring or identifying work ability. However, theoretical research and models can create a conceptual framework for understanding and assessing work ability. From a biomedical point of view, work ability is defined in relation to a person's functional capacity. Independent of work- and life conditions, work disability is considered to be an individual incapacity where a person is unable to perform certain activities due to a medical condition. During the last decades, the biomedical model has been called into question and more comprehensive perspectives on work ability have developed. Models based on a so-called biopsychosocial view have emerged where work ability is assessed as the individual's functional capacity and reduction in activity and participation, in particular the ability to perform ordinary work tasks [4]. In line with this perspective, theoretical research has generally advocated a holistic view on work ability, which is discussed as a multidimensional and relational concept. It is emphasized that the assessment of work ability must be made in relation to a set of circumstances and requirements [5-7] Ilmarinen (2001) describes work ability as a result of the interaction between individual and work and reflects a process of how human resources are related to physical, mental and societal demands at work. Human resources involve components such as health, functional capacities, education and motivation [5].

Nordenfelt (2008) develops these ideas further and identify internal factors, opportunities and requirements as central dimensions for determining work ability. Internal factors comprise a person's health and formal competence but also various forms of personal characteristics such as being flexible and responsible, taking initiatives and being loyal to the employer. The opportunity dimension comprises various circumstances, in particular the work environment 
and whether the employer can make adjustments to the workplace. Opportunity for work also presupposes the existence of a job at the labour market, and whether there is an employer who is willing to employ the individual. The requirement dimension involves the goals of the specified work, for example what kind of tasks and duties that the employee is required to complete in order to have work ability at the workplace. Thus, work ability is dependent on the characteristics of the individual, the work environment and the specific tasks in interaction [7].

There is also research that analyzes how concepts such as work ability, disability and employability are constructed as categories within the social- and labour market policy [8-12]. These studies show how the categorization of individuals' work ability is created in a social and economic context where norms and values in the society have an impact on welfare state organizations' assessments' of work ability. Demands and changes at the labour market affect for example the assessments of work ability and employability [8-9]. These studies emphasize that the focus on abilities is an expression of an individualization of social responsibility where reasons for social exclusion from the labor market (such as sickness absence and unemployment) are attributed to individual weaknesses and factors related to health. From this point of view, the individual is the subject for adaptation, change and activation in order to obtain and sustain work ability [8-12].

The described perspectives and theoretical definitions of work ability are summarized in Table 1.

(Table 1 about here)

To this point, studies that aim to improve knowledge about the relation between theoretical aspects of work ability, in relation to regulations and practice in work ability assessments are sparse. This study focuses on the assessment of work ability within the Swedish social insurance system, and how actual practice is related to regulations and research regarding work ability. 
Aim

The aim of this study is to analyze central stakeholders' perspectives on work ability by studying multi-stakeholder meetings held to discuss sick-listed individuals' work ability and rehabilitation needs. The focus is on how the different stakeholders interpret, discuss and assess work ability in relation to theoretical and legal aspects of work ability.

\section{The Swedish Social Security System}

Sweden's social security system has been described as a social democratic welfare regime, with high replacement rates and active labour market policies [13]. The recent development of the system has been characterized as a movement from structural social security through income insurance toward individualized measures for supporting people's participation on the labour market [14]. With an increased emphasis on individual responsibility and duty towards the society, social rights have to a greater extent become associated with work and activity. A basic idea with this development is to promote activation: all citizens (including the most disabled ones) shall take responsibility for their own and the society's development, based on the assumption that work in itself leads to good health and well being [2].

In Swedish legislation, disease and work inability are the two basic criteria for entitlement to compensation from the public sickness insurance. To be eligible for sickness benefits, three conditions need to be fulfilled. Firstly, there must be a medical diagnosis, which secondly implies a reduction of the individual's functional capacity. This reduction, thirdly, must imply work disability to at least $25 \%$. In the assessment of work ability, social or economic circumstances must not be taken into account. After a certain period of time, the assessment is broadened from the specific job to the labour market at large.

Between the late 1970s and mid 1990s the regulation regarding citizens entitlement to sickness benefits took into account occupational, economic and social related conditions. However, during the mid 1990's, regulations changed, where it was clarified that the assessment of right to sickness benefits should be based solely on medical criteria. From that time, work disability in Swedish legislation is largely defined from a biomedical point of view, that is, as an individual problem caused by an injury or disease. Entitlement to compensation should only be assessed in relation to how the disease affects the ability to work. The starting point at policy level was that if an individual has difficulty maintaining 
employment despite diseases it is primarily a labour market problem - and therefore not a responsibility for the sickness insurance and the Swedish Social Insurance Agency [15]. The aim of these changes was to reduce the economic costs of the sickness insurance by reducing the number of people who are entitled to sickness benefits [15].

The main actor in Swedish social insurance is the Swedish Social Insurance Agency (SSIA), which is a governmental authority responsible for administrating and coordinating sickness insurance and return to work. Meanwhile, a large number of other organizations, professions and disciplines are involved in this process, mainly physicians and rehabilitation professionals in primary or occupational health care, employers, the Swedish Public Employment Service and municipalities. These stakeholders have all different tasks and responsibilities in the return to work process of sick-listed individuals.

\section{Methods}

\section{Study Setting and Sample}

To facilitate stakeholder communication, "status meetings" were introduced in Swedish social sickness in 2003. The status meetings were formulated at the policy level as a tool that would benefit both the citizen and society in terms of reduced costs for people on sick leave [16]. A status meeting is formally described as a multi-stakeholder meeting in which the sick-listed person, the SSIA and at least one additional stakeholder (for example the physician or the employer) participates. The legislation underlines that the intention with the status meeting is to assess the individual's work ability and rehabilitation needs [17]. The assumption is that, by bringing the stakeholders together "around one table", the meeting will lead to a joint assessment of work ability and appropriate interventions that promote the individuals' return to work process. The basic idea behind the status meeting is the expectation that the meeting will create cooperation and consensus among involved actors and promotes an effective return to work. The status meeting as a policy instrument has both a controlling and a supportive function. The controlling function is to gather information to assess an individual's right to sickness benefits, while the supporting function is consideration of rehabilitation measures that will promote return to work. 
(Fig 1 about here)

\section{Data collection}

The data of this study comprise nine digitally recorded status meetings collected from 2007 to 2008 in Sweden by one researcher (PB) taking part in the meetings as a non-participating observer [18]. SSIA team managers were contacted and asked to invite SSIA officials to participate in the study. Six officials contributed with in total nine meetings. Stakeholders participating in the meetings were representatives from the SSIA, the Swedish Public Employment Service, healthcare, employers and, in one case, the union (see Table 2).

(Table 2 about here)

Some workers were sick-listed and partially employed; others were sick-listed and unemployed. The ambition was to obtain a large variation of participants regarding the sicklisted persons' sex, age, time on sick-leave and diagnoses. However, the sample criteria were more difficult than expected to achieve regarding variation in diagnoses. The most obvious reason seemed to be related to the fact that all people involved needed to have time to be consulted and give their consent for participation in the study. Another reason could be a reorganization of the SSIA that took place at the same time which may have increased the workload for the officials participating in the meetings. In light of this, all meetings available to the researchers were included in the study.

The status meetings lasted on average 40 minutes. The shortest meeting took 20 minutes and the longest 1 hour and 50 minutes. The digitally recorded meetings were transcribed verbatim. The analysis in this article is based on the recordings and transcriptions from the meetings.

\section{Method of Analysis}

A qualitative content analysis of the status meetings was carried out [19]. The study examined the manifest and latent content of the material with a focus on both the visible components and underlying meaning of the text [20]. The analysis process was performed in several steps 
and the authors met regularly to systematically discuss the categorization of the empirical material. Initially, the meetings were listened to and read through several times by the first author (IS) which resulted in a preliminary thematization of the material. This contained a description of phases in the meetings (such as discussions about the aim of the meeting, medical condition, rehabilitation and return to work). Based on these phases, stakeholders' perspectives on work ability were interpreted in collaboration with all authors. The suggested thematization was discussed and revised several times until the authors agreed on a thematic structure that was well grounded in the data material.

Minor corrections in citations have been made to improve readability. Transcripts were edited so that potentially identifying information like names, places and workplaces were modified or deleted entirely.

The study was approved by the regional ethics board in Linköping, Sweden. The study took into account basic ethical principles concerning informed consent, confidentiality and not causing harm to participants.

\section{Results}

The meetings took place in an intersection between organizations with different rules and organizational logics. The discussions were characterized by a negotiation of work ability, which had consequences for which of the actors should take responsibility for the rehabilitation process. Three perspectives on work ability became apparent: a medical perspective, a workplace perspective and a regulatory perspective.

\section{Work Ability as a Medical Question}

The discussions during the first part of the meetings were mainly characterized by a medical and individual perspective on work ability. The sick-listed persons' health and disability served as starting points for the discussions on work ability and return to work. The causes of the persons' sick leave were formulated in medical terms such as "neck and back pain", "nerve damage" and "age-related changes". It was especially the sick-listed person and representatives from health care who played a prominent role in this phase; sick listed persons (at the request of the SSIA officials) described how their injuries or diseases occurred, their 
contacts with health care, medical treatment, rehabilitation and how their conditions affected their everyday life. The physical conditions were formulated as the main problem for sickness absence, and barriers for return to work were explained from a medical perspective. Health care professionals were asked to provide forecasts on the individuals' recovery and return to work.

SSIA: What do you make of the prognosis, [the physician]?

Health care: Yes, I suppose it's as [the sick-listed person] says. The healing of nerve damage is something we can't affect a great deal medically. However, function is of course a different matter. It's sometimes possible to function pretty well even though it hasn't healed, so to say. It's about how much discomfort you're in but the healing process itself is something you can't really do much about. As he said, it can sometimes take up to a year before it has healed, if it heals completely at all. [...] However, functionally it gets better up to a certain level but the end result is impossible to predict. Nevertheless it has improved although it's now come to a halt. (Status meeting 4)

Medical professionals like physicians, physical therapists and occupational therapists had a central role in defining the prerequisites for returning to work, and in a few examples (where the individual was unemployed), rehabilitation professionals in alliance with the individual tried to convince the SSIA official of the importance of work oriented efforts (e.g. education or work placement). Health care representatives could also take the role as a "spokesperson" for the sick-listed person in question by describing the individuals' situation and problems to the SSIA official. In these cases the sick listed individuals had a relatively withdrawn role and the discussion was mainly between the health care and the other involved stakeholders.

SSIA: But you're right. These water exercises that made [the sick-listed person] feel better. Is it possible to take it up when the knee is better?

Health care: Yes, she didn't actually complete it. Generally there's a fifteen session training allowance. During a time period of seven-eight weeks and they weren't actually completed. We interrupted them after you'd been for physiotherapy or to the swimming pool a few times right? And then you fell and suffered a fracture. So you had actually just started so to say.

SSIA: So when will the arm be completely healed?

Health care: I suppose middle of March, beginning of April sometime, depending on the progress of the pain and mobility it's possible to take it up again. (Status meeting 8) 
Except illustrating health care representatives' role as spokespersons, the quotation also show the importance of medical statements during meetings. Health care actors represented the "expert knowledge" in terms of their medical certificates, medical assessments and statements which SSIA officials requested and took into account. The importance of medical information became particularly apparent in cases when medical reports from physicians were missing or when health care representatives were not present during meetings.

\section{Work Ability as a Workplace Question}

Generally, in the second part of the meetings, work ability was discussed in relation to workplace demands. The stakeholders raised various factors related to the workplace or working life that were considered influential for determining the individuals' work ability. The SSIA officials highlighted the workplace as an arena for possible adjustments in order to regain and sustain work ability. Officials' questions to the employers concerned possibilities for part time work, alternative placements, changed work tasks and the access to working tools.

Employers, on the other hand, mainly emphasized workplace barriers for individuals' return to work. Employers (and at times also the sick-listed persons themselves) often stressed the individuals' lack of health in relation to work demands. Thus, employers generally referred to a medical perspective on work ability to legitimize why the individual could not return to work and why they experienced difficulties in adjusting the workplace. Medical treatment and rehabilitation was preferred to workplace adaptations for regaining work ability. This focus on barriers may be exemplified with an individual on sick leave from a decorator company.

SSIA: I see, what about the workplace, is there any possibility of making adjustments there in order to facilitate [the sick-listed person] return to work? Is it possible to sort of make things easier in the beginning?

Employer: No, in our line of business there isn't. There are no simplified tasks if you are to be a decorator. It's a small business; there is no alternative work.

SSIA: No? What about a reassignment?

Employer: No. You see, it's not possible.

SSIA: No, no.

Employer: What I mean, whatever we do [the sick-listed person] still has to climb up on a [decorator] buck. We can't look for work that only reaches 1.50 high. Most often it's 2.50. That means we want the whole wall painted. (Status meeting 6) 
In some meetings, where the demands at work were perceived as too high, employers and sick-listed individuals agreed about the impossibility of returning to the workplace, displaying an alliance for maintaining the sick leave.

SSIA: And then there's the possibility of workplace adjustment? How does that look?

Employer: Dreadfully limited.

Sick-listed: Yes, it is isn't it.

Employer: We have to go in and out of all the cars. Why, that's some 80 steps in and out of cars every night.

Sick-listed: And steps and cleaning.

Employer: Yes. And it is 10 hours night time work on a full time basis. (Status meeting 3)

The workplace perspective was also reflected when causes of ill health were discussed, especially when the problems could be related to poor working conditions. In one meeting, a physical therapist described the sick-listed person's condition as related to factors at the workplace:

Health care: The cause of these types of problems is of course really difficult to say, that is, when there's no acute trauma involved. But the way you described your working situation before this came about or at the time it came about was that you found it very stressful at work, that there were a lot of work tasks that you didn't have time to do. You felt that you didn't have time for coffee breaks and worked overtime without pay just to manage. (Status meeting 8)

Besides work demands, employers also emphasized the production perspective and the economic goals of their organization. The size of the company seemed to matter for the possibility to find alternative work tasks, which was described as more difficult in smaller companies. Employers suggested that the responsibility for rehabilitation and workplace adjustments was restricted by the economic limitations of the organization.

Employer: We are obliged to adjust as much as possible but - but there has to be a need. There has to be a job that a manager is willing to pay a salary for. (Status meeting 7)

Although employers often expressed difficulties in adjusting workplaces, there were also meetings where employers had or were intending to adjust the workplace. In one example, an 
employer suggested that an ergonomist from the occupational healthcare should assess the physical work environment in relation to the individual's work ability.

Employer: But I'm considering if I should just ask an ergonomist from the occupational healthcare to come to the workplace and shadow you during a day at work and see if they can give some suggestions. If there's something we can purchase, a workplace aid of some sort, what do you think about that?

Sick-listed: I'm sure many would benefit from that. I think so.

Employer: What about you?

Sick-listed: And me. [...] Because it's that type of building. It's run down, it's old and all that. So sure that would be good. (Status meeting 7)

The discussions on return to work often ended up with an assessment of the relation between the individual's physical capacities and the job requirements. Employers took different perspectives on work place adjustments, depending on the influence of the production perspective.

\section{Work Ability as a Regulatory Question}

One purpose of the status meeting for the SSIA is to facilitate assessments of individuals' right to economic compensation and rehabilitation measures from the sickness insurance system. In several cases it became apparent how the SSIA officials strove to classify individuals' work ability in relation to administrative categories. The regulatory framework was reflected through the assessment of individuals' work ability in fixed percentages in relation to compensation levels in the sickness insurance. The assessment of work ability as an administrative categorization thus became something all stakeholders related to and took into account.

SSIA: Thirty hours a week? No, the levels we have are 25, 50, 75 and 100 [percent] based on fulltime work. [...] These are our levels when it comes to sickness benefits. (Status meeting 2)

At one meeting, it became clear how the physician had to adapt the work ability assessment to SSIA's regulatory framework and estimate the degree of the individual's work ability in percentages. During the meeting, the physician expressed uncertainty about quantifying work ability, and emphasized the importance of finding a suitable work environment. 
Health care: So to work 100 percent I can't say that, I can't comment on that. I say what the Xray says. But I don't know. I also think it's to find a place that's good. You yourself mentioned the concrete floor [...]. So we'll have to see if 50 percent, we can see which environment would suit you. At least that's the goal. (Status meeting 7)

The quote illustrates a genuine uncertainty about the level of work disability. However, the vague estimation of "50 percent work ability" still became relevant for how the SSIA official summarized the meeting.

SSIA: But if we summarize somewhat here now as I understand it [physician] still estimates that it's a half-time job that - that one might have to settle for. And in that case I want a medical certificate from [physician] to see if it verifies the other half of the sickness benefit. (Status meeting 7)

In this example, the uncertain assessment of the physician was translated into a formal decision, where work ability was estimated in relation to the regulatory framework, and where the uncertainty in this stage was downplayed. Estimations from physicians were generally a key factor and used as objective statements, which also became apparent in cases when reports from physicians were missing or when actors from health care were not present. In these situations, there was an interruption of the meeting because medical information was missing and it became difficult to continue and make decisions.

\section{A Negotiation of Responsibility}

The status meeting took place on an arena where multiple organizations with different rules and practices are represented, and it often developed into a kind of negotiation regarding which organization was responsible for the sick-listed person. The negotiations concerned responsibility for workplace adjustments, rehabilitation efforts and financing. In these situations it became clear how different regulations and organizational logics influenced different stakeholders' arguments. Health care representatives mainly emphasized medical barriers for the individual's return to work, while the SSIA people generally argued from a regulatory point of view, trying to get other stakeholders involved in the individuals' return to work processes. Employers frequently referred to a medical perspective to legitimize the person's sick leave and absence from work, while simultaneously expressing difficulties about making workplace adjustments. 
The SSIA officials often asked employers about possible workplace adjustments, using medical statements to legitimize their suggestions, for example when an official referred to a medical certificate saying that the sick-listed person should avoid heavy lifting and that administrative working tasks were preferred. The discussions regarding workplace adjustments developed into a negotiation between the SSIA official and the municipal employer.

SSIA: But I was thinking why are you in a school? Is it junior or intermediate level?

Sick-listed: Upper secondary level.

SSIA: Upper secondary level. Yes, because I had this thought, there isn't anywhere one can step in either. I was thinking if it was junior or intermediate level.

Employer: You are well aware that we don't transfer. No, we don't rehabilitate anywhere but back to the position you were employed for.

SSIA: Yet sometimes there are solutions so it's best to look at them anyway. (Status meeting 2)

All stakeholders treated medical statements as descriptions of objective facts, to legitimize their positions. Professionals such as physicians, physical therapists and occupational therapists thus came to represent "expert knowledge". Employers referred to the health care system being responsible of the individual. In one meeting, the employer pointed out that the responsibility lies on health care system if the individual does not have work ability after medical treatment and rehabilitation. The employer argued that it is a medical matter whether the person can work in the future, revealing a clear demarcation in the perception of work ability and rehabilitation responsibilities.

Employer: If the doctor says hundred [100\% work ability], well then she is fully recovered.

Sick-listed: In that case one should be able to manage ones work without it needing to be adjusted.

Employer: and then it's actually a medical question if she can't. [...] If [the sick-listed] can't work then it's really a matter between the doctor and [the sick-listed]. (Status meeting 1)

In cases where the individual was sick-listed and unemployed, a representative from the Swedish Public Employment Service could participate in the meeting. At one meeting, there was a disagreement between the officials from the SSIA and the Public Employment Service where the regulations of the two governmental organizations collided. The Public 
Employment Service could not start an intervention with the individual before SSIA had completed the case. They required that the individual be re-categorized from "sick-listed" to "unemployed", which in bureaucratic terms would imply that the Public Employment Service had the formal responsibility for the person and thus could initiate labour market measures.

Swedish public Employment Service: To begin with, the requirement is that he isn't sick-listed but unemployed. Although we don't go in and launch an investigation if he needs more medical rehabilitation. In which case we don't initiate anything.

SSIA: No. Because that was the thought if you could even though [the sick listed individual] is sick-listed, you could still could go in and do something

SPES: No, it's SSIAs' responsibility in that case. (Status meeting 4)

The discussions during the meetings revolved around a variety of medical and workplacebased obstacles for return to work. In more complex cases involving people who were both sick-listed and unemployed, the individuals' education and their work experience sometimes was considered, in terms of different forms of active labour market-oriented measures for SSIA to apply in order to promote work ability and the entrance of the individual to the labour market.

In summary, three perspectives on work ability were identified in the analysis: a medical perspective, a workplace perspective and a regulatory perspective. SSIA frequently emphasized the workplace's central role to promote work ability of the individual. Contrary to this, employers mainly stressed medical impairments and workplace requirements as main problems for the employee's ability to work. Health care actors regularly emphasized medical barriers and obstacles which were assumed to reduce the individual's work ability. It also became apparent how the stakeholders' assessments of work ability were affected by the regulatory framework in the sickness insurance. Although different perspective on work ability could be linked to specific stakeholders, the actors often adapted their positions to each other's perspectives through negotiations. Table 3 reviews different factors that the stakeholders' emphasized as important for work ability and return to work, as they emerged in the analysis of the empirical material.

(Table 3 about here) 


\section{Discussion}

One formal objective with the status meeting was for involved actors to collaborate to meet the rehabilitation needs of the individuals. However, contrary to policy ideal the results show how the meetings developed into an arena for negotiations about work ability and who was responsible for the individual's rehabilitation, return to work and financial support. In these negotiations it became clear how stakeholders used medical statements as objective facts to legitimize arguments about work ability and return to work. The meeting maintained organizational boundaries rather than overcame them; the discussions were based on different institutional needs, with the individuals' needs as only one element. The findings demonstrate an unequal distribution of power among cooperating actors where the employers was an influential negotiator because they were able to say that they can or cannot accommodate the individual.

\section{Work Ability as Relational but Dependent on Medical Statements}

The results of the study show how individuals' work ability and opportunities for return to work were not only dependent on the medical assessment of disability, but largely also on employers' offer of workplace adjustments. Hence, the assessment of the work ability is in practice based on the relationship between individual abilities and job characteristics, rather than the strict medical assessment [5-7].

However, the medical statements were of great importance in the discussions of work ability and return to work. The stakeholders had difficulties with arguing around work ability and return to work without support from medical statements, which came to serve as objective expert opinions in the discussions. The medical statements were used to legitimize the stakeholders' different standpoints regarding work ability and return to work measures. When employers expressed difficulties in making workplace adjustments, medical statements were consulted for classifying the situation as based on medical problems, which could mainly be addressed through medical treatment and rehabilitation. Although the medical statements were sometimes based on vague estimations, these statements and the quantitative assessments of work ability (in fixed percentages) were used by the stakeholders to legitimize their perspectives on whether or not they should be responsible for making rehabilitation measures. In light of this, the process of assessing work ability during the status meeting can be understood from a regulatory perspective, where involved actors have to adapt the work 
ability assessments to the sickness insurances' regulatory framework. From a welfare state perspective the assessment of work ability can be understood as an administrative categorization that helps SSIA to distinguish those individuals who are entitled to benefits provided by sickness insurance [21-22].

Medical assessments have in most western countries come to play an increasingly important role in decisions about peoples' right to social benefits [22-23]. The influence of medical expertise and medical professions has increased within welfare state institutions both on a policy level and in local practice. In Sweden and other western countries, physicians have a central function in assessing work disability, which makes them gatekeepers to benefits from the sickness insurance [24]. Health care professionals thus have a prominent role in identifying problems and solutions for work disability. This development has in the literature been described as a form of medicalization, where social and personal conditions are transformed and labeled as medical and individual problems, and contextual and environmental factors (such as work environment and work organization) are often downplayed [25].

\section{Employers' Impact on Work Ability}

The focus on individuals' work ability and active interventions imposes several requirements on the involved organizations. The SSIA has an overall responsibility for individuals' sick leave and return to work. The findings of this study illustrate the importance and influence of employer perspectives in this process. A condition for work ability and return to work is employer provision of workplace accommodations and the very existence of a job to which individuals can return. These findings go in line with Nordenfelt's theoretical analysis of work ability where the opportunity- and requirement dimensions of the concept emerged as central elements in the discussions [7]. Employers' offer of workplace adjustment influenced the overall assessment of work ability. Demands at work and what kind of tasks the employer expected the individual to perform also affected the understanding of work ability.

Globalization, new technologies and the transition from an industrial to a knowledge- and service-based society have resulted in new working tasks and jobs [26]. New relations between employers and employees have emerged due to a transition from regular long term employment towards part-time and temporary work arrangements [27]. Today's flexible work life is demanding for the individuals, as reflected in an under-representation of employees 
with disabilities in the Swedish labour market [28]. This study show how both work requirements and employers' need of manpower affected the stakeholders' perspectives and attitudes towards work ability and rehabilitation efforts [7]. Employers emphasized for example that there must be a "need" and a "demand" of manpower before being able to adapt working tasks. This production-oriented perspective on work ability became apparent when economic goals and costs were stressed as factors that influenced employers' ability to make accommodations. These findings are in accordance with other studies that underline employers' cost concerns regarding return to work measures or hiring people with disabilities [29-30]. Meanwhile, previous research shows a relation between company size and the presence of return to work measures. In comparison with larger companies, small and medium sized companies generally put less financial resources on health and safety activities [31]. Baril et al (2003) showed that larger companies have a more generous approach regarding health and safety management, which enabled work modifications [31]. Larger companies also have a variety of working tasks to offer, which allow employees with reduced work ability to work temporarily with things that are less demanding [31]. However, it appears that small company size is not the only constraint. In this study, one of the larger employers, a municipality, did not utilize the opportunities to find other work tasks within the organization and stated that return to work only was possible to the original job. Indeed, a lack of health and safety resources and a lack of clear local policies for managing early return to work can result in solutions based on expense avoidance rather than on work rehabilitation. Employers tend to focus on their own business and production logic [29].

Previous studies have emphasized the importance of workplace adjustments to ensure individuals' health and work ability. High adjustment latitude at workplaces has been shown to increase peoples' likelihood of returning to work after being on long-term sick leave [3233]. Modified work programs have also been shown to facilitate employees' return to work and reduce the number of lost work days [32]. However, as the health needs of the worker can be at odds with the financial needs of the employer, these programs may not always be implementable.

\section{Barriers for a Common Holistic Approach and Responsibility}

Studies of work disability prevention have shown that the workplace, the health care system and the compensation system (and their interactions) have an impact on individuals' practical opportunities to return to work. Increased communication, cooperation and a broader 
understanding of work disability are identified to be of great importance for a successful return to work process [34-35].

The findings demonstrate that the assessment of work ability took place in the intersection between organizations with different rules and logics, where organizational boundaries implied difficulties for stakeholders to collaborate and agree on responsibilities and common solutions for return to work efforts. It seemed difficult to attain a common holistic approach on work ability and the return to work process. The SSIA's focus on return to work in several cases collided with the employers' perspectives, where it was emphasized that the individual's work ability was not consistent with the production requirements at the workplace. The assessment of work ability was thus in practice influenced by the stakeholders' views on what measures were necessary to regain work ability and return to work. Although both the SSIA officials' questions about possible workplace adjustments and the employers' arguments about work requirements illustrate a relational analysis of the concept, the negotiations among the actors still often developed into medical discussions, where work disability was formulated as a medical problem that could mainly be addressed through medical treatment and rehabilitation [7]. From an employer perspective, it was reasonable to argue that work disability was a medical matter and therefore the responsibility of the health care system. In cases where employers did not consider themselves able to adapt the workplaces, the SSIA officials had little room for action. Hence, it was the employer's interpretation of the medical statements that often determined whether or not a person could return to work, i.e., whether they were work disabled or not.

A lack of a holistic and common social responsibility of the individual can be understood in relation to administrative changes in the public sector since the 1980s. Based on ideational goods of New Public Management, the public sector in western countries has undergone innumerable reforms in the last decades [36-38]. The development has been described as a rise of an "audit society" where businesslike measurement models have been introduced in order to measure public sector performance [39]. Positive arguments behind the New Public Management-reforms are that they will result in an efficient public sector with an increased transparency of the administration. The focus on accountability is assumed to lead to better organizational performance, improved service and attention to the authorities" "clients" or "customers" [40]. However, organizational research shows that in line with the implementation of these regulating principles, strong organizational identities within the 
public sector have emerged, in terms of increased autonomy, boundaries and collective resources among public services [41]. Collaboration in itself may hence be a popular term to use, but difficult to realize because regulations, goals and guidelines between organizations are different.

The findings of this study demonstrate difficulties for the welfare state organizations and employers to have a holistic view on the individual and share a common social responsibility of the citizens. Multi-stakeholder meetings as a work method for collaboration and consensus around work ability and return to work hence runs the risk of maintaining organizational boundaries rather than being a tool to overcome them. The results also highlight the power dimension of multi-stakeholder arrangements. The analyses of the status meetings demonstrate an unequal power distribution among cooperating actors where the employers often determined whether or not persons could return to work.

\section{Methodological Considerations}

This study is based on an empirical material from regular practice, and the recorded status meetings would have taken place regardless of the study. Through non-participating observations it has been possible to directly capture cultural and social aspects of the discussions, which is a strength of the study. The selection of studied meetings was done by SSIA team managers, who invited SSIA officials to participate in the study. Therefore, there is a possibility that the meetings offered by the SSIA officials were considered to be uncomplicated case. Another possible limitation is that a majority of the meetings were based on cases where the diagnosis was of a physical character, which may have affected the stakeholders' discussions on work ability and return to work measures. The material further consists of a relatively small number of meetings. However, there are no reasons to assume that the results from this study cannot be transferred to other meetings and contexts, since organizational cooperation such as multi-stakeholder meetings involving assessments of work ability is frequent in a Swedish and an international context. The credibility of the study is strengthened by discussions and examinations of the co-authors during the analytic process. Emerging findings and manuscripts have also systematically been discussed as continuous quality checks in order to achieve trustworthiness. 


\section{Conclusions}

The aim of this study was to analyze central stakeholders' perspectives on work ability by analyzing how actors in multi-stakeholders meetings interpreted, discussed and assessed work ability in relation to theoretical and legal aspects of the concept. The results of the study illustrate that the theoretical analysis of work ability presented in the introduction is applicable also to local practice [5-7]. In particular, the opportunity- and requirement dimension in Nordenfelt's theoretical analysis of work ability emerged as central elements. [7]. The findings demonstrate difficulties for actors within the Swedish welfare system to assess work ability from a common holistic point of view and to share a social responsibility of the individual. Instead, the meetings developed into negotiations of responsibility concerning workplace adjustments, rehabilitation efforts and financial support. In the negotiations, the employers had the "trump card" due to their possibilities to offer workplace adjustments, illustrating an unequal distribution of power among the cooperating actors. The existence of alternative or adjusted working tasks at the workplace hence often determined whether persons could return to work, i.e., whether they were considered to have work ability or not. Finally, this study encourages further research on the balance of power within multistakeholder arrangements and how actors' different organizational logics, interests and power resources can affect assessments of work ability and return to work processes of individuals.

\section{Acknowledgement}

The authors would like to thank Ellen MacEachen for valuable comments during the finalization of the manuscript. 


\section{References}

1. MacEachen E, Kosny A, Ferrier S, Lippel K, Neilson C, Franche R. L, Pugliese D. The 'Ability' Paradigm in Vocational Rehabilitation: Challenges in an Ontario Injured Worker Retraining Program. Journal of Occupational Rehabilitation. 2011; doi: 10.1007/s10926-0119329-x.

2. Holmqvist M. The active welfare state and its consequences. European Societies. 2010;12(2):209-30.

3. De Boer W. Quality of evaluation of work disability. Hoofddorp: TNO Quality of Life; 2010.

4. World Health Organization. Classification of Functioning, Disability and Health (ICF). Geneva: WHO; 2001.

5. Ilmarinen JE. Aging workers. Occupational \& Environmental Medicine. 2001;58(8):546-52.

6. Tengland P-A. The Concept of Work Ability. Journal of Occupational Rehabilitation. 2011;21(2):275-85.

7. Nordenfelt L. The Concept of Work Ability. Bruxelles: P.I.E. Peter Lang; 2008.

8. Garsten C, Lindvert J, Thedvall R, editors. Arbetets marknad: Arbetsmarknadens nya organisering. Malmö: Liber; 2011.

9. Garsten C, Jacobsson K. Sorting people out: Detecting and classifying employability, work capacity and disability at Swedish Public Employment Services. International Sociological Association-conference; Guthenburg 2011.

10. Garsten C, Jacobsson K, editors. Learning to be employable: new agendas on work, responsibility, and learning in a globalizing world. Basingstoke: Palgrave Macmillan 2004.

11. Peralta Pierto J. Den sjuka arbetslösheten: Svensk arbetsmarknadspolitik och dess praxis 1978-2004. Uppsala: Uppsala University; 2006.

12. Lindqvist R. Funktionshinder, arbetsförmåga och socialpolitik. In: Westerhäll L, editor. Arbets(o)förmåga - ur ett mångdiciplinärt perspektiv. Stockholm: Santérus; 2008.

13. Esping-Andersen G. The Three Worlds of Welfare Capitalism. Cambridge: Polity Press; 1990.

14. Jacobsson K. A European Politics of Employability: the Political Discourse on Employability of the EU and the OECD. In: Garsten C, Jacobsson K, editors. Learning to be employable: new agendas on work, responsibility, and learning in a globalizing world. Basingstoke: Palgrave Macmillan; 2004. 
15. Vahlne Westerhäll L. Det sjukförsäkringsrättsliga arbetsförmågebegreppet i lagstiftning och rättstillämpning. In: Vahlne Westerhäll L, editor. Arbets(o)förmåga: ur ett mångdisciplinärt perspektiv. Stockholm Santérus; 2008.

16. Proposition. Förändringar inom sjukförsäkringen för ökad hälsa i arbetslivet 2002.

17. Riksförsäkringsverket. Om avstämningsmöten 2003.

18. Hammersley M, Atkinson P. Ethnography: Principles in practice. London: Routledge; 1995.

19. Patton MQ. Qualitative research \& evaluation methods 3. ed. London: SAGE; 2002.

20. Graneheim UH, Lundman B. Qualitative content analysis in nursing research: concepts, procedures and measures to achieve trustworthiness. Nurse Education Today. 2004;24(2):20930.

21. Johansson R. Vid byråkratins gränser: Om handlingsfrihetens organisatoriska begränsningar i klientrelaterat arbete. Lund: Studenteratur; 1992.

22. Stone D. The disabled state. Basingstoke: Macmillan; 1985.

23. de Swaan A. In care of the State. Health Care, Education and welfare in Europe and the USA in Modern Era. Cambridge Polity Press; 1990.

24. Löfgren A. Physicians' sickness certification practices: frequency, problems, and learning. Stockholm: Karolinska Institutet 2010.

25. Conrad P. Medicalization and Social Control. Annual review of sociology 1992;18:209-32.

26. Castells M. The information age: economy, society and culture. The rise of the network society. Malden, Mass: Blackwell; 2000

27. Garsten C. Workplace Vagabonds. Basingstoke: Palgrave Macmillan; 2008.

28. Swedish Public Employment Servic. Statistics on unemployed at the Swedish Public Employment Service 2010.

29. MacEachen E, Kosny A, Scott-Dixon K, Facey M, Chambers L, Breslin C, Kyle N , Irvin E, Mahood Q and the Small Business Systematic Review Team. Workplace health understandings and processes in small businesses: A systematic review of the qualitative literature. Journal of Occupational Rehabilitation 2010;20(2):180-98.

30. Kaye H, Jans LH, Jones EC. Why Don't Employers Hire and Retain Workers with Disabilities? Journal of Occupational Rehabilitation 2011;21(4):526-36.

31. Baril R, Berthelette D, Massicotte P. Early return to work of injured workers: multidimensional patterns of individual and organizational factors. Safety Science 2003;41:277-300.

32. Krause N, Dasinger LK, Neuhauser F. Modified work and return to work: a review of the literature. Journal of Occupational Rehabilitation 1998;8:113-39. 
33. Johansson G, Lundberg O, Lundberg I. Return to work and adjustment latitude among employees on long-term sickness absence. Journal of Occupational Rehabilitation 2006;16(2):181-91.

34. Pransky G, Shaw W, Franche R. L, Clarke A. Disability prevention and communication among workers, physicians, employers, and insurers - current models and opportunities for improvement. Disability and Rehabilitation 2004;26(11):625-34.

35. Loisel P, Durand M-J, Berthelette D, Vézina N, Baril R, Gagnon D, Larivière C, Tremblay C. Disability Prevention: New Paradigm for the Management of Occupational Back Pain. Disease Management \& Health Outcomes 2001;9(7):351-60.

36. Pollitt C, Bouckaert G. Public Management Reform. Second ed. New York: Oxford University Press; 2004.

37. Hughes OE. Public Management \& Administration: An Introduction. New York: Palgrave; 2003.

38. Hood C. A public management for all seasons? Public Administration 1991;69(1):3-19.

39. Power M. The Audit Society. Rituals of Verification. Oxford: Oxford University Press; 1997.

40. Sahlin-Andersson K. National, international and transnational construction of new public management. Stockholm Centre for Organizational Research working paper series 2000:4.

41. Brunsson N, Sahlin-Andersson K. Constructing Organizations: The Example of Public Sector Reform. Organization Studies 2000;21(4):721-46. 


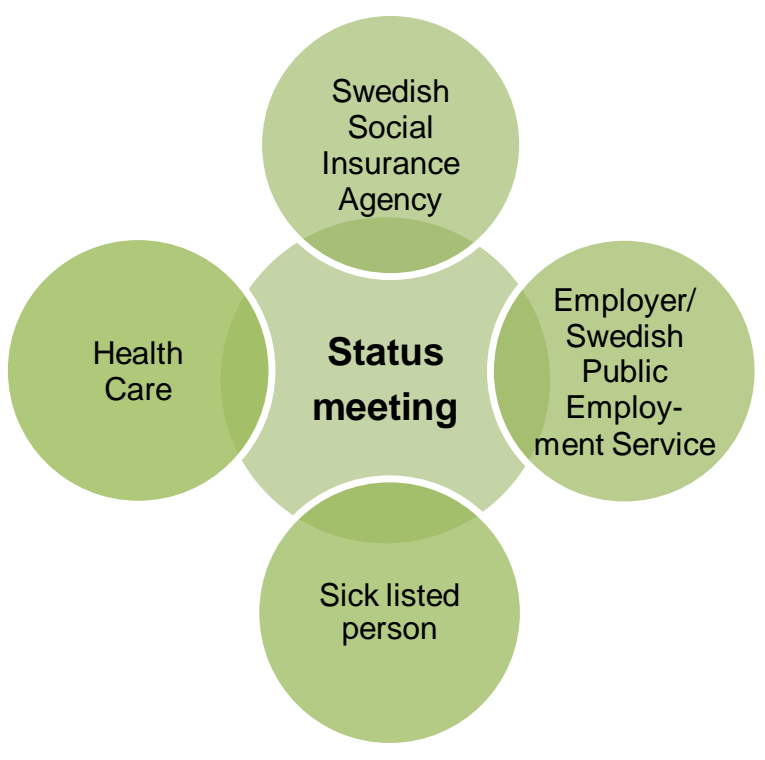

Fig. 1 The status meeting as a multi-stakeholder arena to assess work ability and return to work. Union representatives may participate on request of the sick-listed person. 
Table 1: An overview of theoretical definitions and perspectives of work ability.

\begin{tabular}{|l|l|}
\hline Biomedical perspective & $\begin{array}{l}\text { Work ability as result of functional capacities } \\
\text { due to the individual's medical (physical, } \\
\text { psychological or intellectual) condition. }\end{array}$ \\
\hline Biopsychosocial perspective & $\begin{array}{l}\text { Work ability as a result of individual } \\
\text { characteristics, work environment and } \\
\text { specific task in interaction. }\end{array}$ \\
\hline Social perspective & $\begin{array}{l}\text { Work ability as a social construction } \\
\text { influenced by political, cultural and } \\
\text { economic factors in the environment. }\end{array}$ \\
\hline
\end{tabular}

Table 2: Descriptions of participants in their status meetings.

\begin{tabular}{|c|c|c|c|c|}
\hline $\begin{array}{l}\text { Status } \\
\text { meeting }\end{array}$ & $\begin{array}{l}\text { Sex/age/employment/ } \\
\text { profession }\end{array}$ & Meeting length & Participants & Health condition \\
\hline 1 & $\begin{array}{l}\text { Women } 40 \text { years old } \\
\text { Employed/Childcare } \\
\text { minder }\end{array}$ & $41 \mathrm{~min}$ & $\begin{array}{l}\text { SSIA/SL/ } \\
\text { Emp }\end{array}$ & Musculoskeletal \\
\hline 2 & $\begin{array}{l}\text { Women } 61 \text { years old } \\
\text { Employed/Cook }\end{array}$ & $34 \mathrm{~min}$ & $\begin{array}{l}\text { SSIA/SL/ } \\
\text { Emp }\end{array}$ & Musculoskeletal \\
\hline 3 & $\begin{array}{l}\text { Women } 47 \text { years old } \\
\text { Employed/Assistant } \\
\text { nurse }\end{array}$ & $21 \mathrm{~min}$ & $\begin{array}{l}\text { SSIA/SL/ } \\
\text { Emp }\end{array}$ & Musculoskeletal \\
\hline 4 & $\begin{array}{l}\text { Man } 42 \text { years old } \\
\text { Unemployed/ } \\
\text { Construction worker }\end{array}$ & $28 \mathrm{~min}$ & $\begin{array}{l}\text { SSIA, SL/ } \\
\text { HC/SPES }\end{array}$ & Traumatic injury \\
\hline 5 & $\begin{array}{l}\text { Man } 46 \text { years old } \\
\text { Unemployed/chef }\end{array}$ & $34 \mathrm{~min}$ & $\begin{array}{l}\text { SSIA/SL/ } \\
\mathrm{HC}\end{array}$ & Musculoskeletal \\
\hline 6 & $\begin{array}{l}\text { Man } 50 \text { years old } \\
\text { Employed/decorator }\end{array}$ & $23 \mathrm{~min}$ & $\begin{array}{l}\text { SSIA/SL/ } \\
\text { Emp }\end{array}$ & Traumatic injury \\
\hline 7 & \begin{tabular}{|l|} 
Man 57 years old \\
Employed/ \\
Construction worker \\
\end{tabular} & $40 \mathrm{~min}$ & $\begin{array}{l}\text { SSIA/SL/ } \\
\text { Emp/HC/ } \\
\text { Union }\end{array}$ & Musculoskeletal \\
\hline 8 & $\begin{array}{l}\text { Women } 62 \text { years old } \\
\text { Unemployed/Cleaner }\end{array}$ & $20 \mathrm{~min}$ & $\begin{array}{l}\text { SSIA/SL/ } \\
\mathrm{HC}\end{array}$ & Musculoskeletal \\
\hline 9 & $\begin{array}{l}\text { Women } 39 \text { years old } \\
\text { Employed/Preschool } \\
\text { teacher }\end{array}$ & $110 \mathrm{~min}$ & $\begin{array}{l}\text { SSIA/SL/ } \\
\text { Emp/HC/ } \\
\text { Other }\end{array}$ & Mental trauma \\
\hline
\end{tabular}

SSIA: Swedish Social Insurance Agency

\section{SL: Sick-listed}

SPES: Swedish Public Employment Service

EMP: Employer

HC: Health care 
Table 3: The stakeholders' perspectives on work ability in a return to work context.

\begin{tabular}{|c|c|c|c|}
\hline & $\begin{array}{l}\text { Work Ability as a } \\
\text { Medical Question }\end{array}$ & $\begin{array}{c}\text { Work Ability as a } \\
\text { Workplace Question }\end{array}$ & $\begin{array}{c}\text { Work Ability as a } \\
\text { Regulative Question }\end{array}$ \\
\hline $\begin{array}{l}\text { Swedish } \\
\text { Social } \\
\text { Insurance } \\
\text { Agency }\end{array}$ & $\begin{array}{l}\text { Work ability is } \\
\text { assessed based on } \\
\text { medical certificates } \\
\text { and how the } \\
\text { diagnose affects the } \\
\text { ability to work. }\end{array}$ & $\begin{array}{l}\text { Work ability depends on } \\
\text { employers' possibilities } \\
\text { to offer workplace } \\
\text { adjustments. }\end{array}$ & $\begin{array}{l}\text { Work ability as an } \\
\text { administrative/bureaucratic } \\
\text { category with the SSIA as } \\
\text { a gatekeeper. Work ability } \\
\text { is assessed in fixed } \\
\text { percentages in relation to } \\
\text { criteria for entitlement to } \\
\text { sickness benefits. }\end{array}$ \\
\hline Health Care & $\begin{array}{l}\text { Focus on medical } \\
\text { treatment and } \\
\text { rehabilitation. }\end{array}$ & $\begin{array}{l}\text { Assessments of work } \\
\text { ability are made despite } \\
\text { limited knowledge of the } \\
\text { workplace. }\end{array}$ & $\begin{array}{l}\text { Requirement to adapt work } \\
\text { ability assessments to fixed } \\
\text { percentages based on } \\
\text { compensation levels in the } \\
\text { sickness insurance. }\end{array}$ \\
\hline Employers & $\begin{array}{l}\text { Medical } \\
\text { impairments as a } \\
\text { main problem for } \\
\text { individuals' } \\
\text { inability to work. } \\
\text { Employers use } \\
\text { medical statements } \\
\text { as expert knowledge } \\
\text { when considering } \\
\text { work ability. }\end{array}$ & $\begin{array}{l}\text { A focus on individuals' } \\
\text { lack of health in relation } \\
\text { to workplace demands. } \\
\text { Production perspective } \\
\text { and economic goals of } \\
\text { the organizations as } \\
\text { important factors. }\end{array}$ & $\begin{array}{l}\text { Employers' possibilities } \\
\text { and willingness to offer } \\
\text { adjustments determine } \\
\text { return to work, and thereby } \\
\text { influence entitlement to } \\
\text { sickness benefits. }\end{array}$ \\
\hline
\end{tabular}

